\title{
Measuring the Satisfaction Levels of Customers of Fresh Vegetables towards the Marketing Mix in Traditional Markets in Sukoharjo Regency, Indonesia
}

\author{
Raya Ilham Syah Majiid ${ }^{1 *}$, Joko Sutrisno ${ }^{2}$ and Umi Barokah ${ }^{2}$ \\ ${ }^{1}$ Master Student in Agribusiness, Postgraduate Program, Universitas Sebelas Maret, Surakarta, Indonesia; \\ ${ }^{2}$ Department of Agribusiness, Faculty of Agriculture, Universitas Sebelas Maret, Surakarta, Indonesia \\ *Corresponding author: rayailhamsmajiid@student.uns.ac.id
}

\begin{abstract}
Vegetables are horticultural crops that have a high market absorption. Modern market that is considered to have many advantages does not necessarily reduce consumers' shopping interest at traditional markets. Traditional markets appear to have different characteristics and visitor segments from modern markets. This study aims to determine the level of consumers' satisfaction of vegetables towards the marketing mix in the traditional markets in Sukoharjo. Data were processed using the Customer Satisfaction Index (CSI) method. The study was conducted from January to March 2019 with 80 consumers of vegetables as the respondents taken using quota sampling technique. CSI analysis was used to measure the level of customers' satisfaction by calculating the rates of indicator performance attached to the items/services given by the consumers. Based on the CSI values, the result of the study conclude that consumers were satisfied with the services provided in traditional markets, which put priority on using family system to create convenient atmosphere of transactions.
\end{abstract}

Keywords: consumers of vegetables; customer satisfaction index; marketing mix; traditional market

Cite this as: Majiid, R. I., Sutrisno, J., \& Barokah, U. (2020). Measuring the Satisfaction Levels of Customers of Fresh Vegetables towards the Marketing Mix in Traditional Markets in Sukoharjo Regency, Indonesia. Caraka Tani: Journal of Sustainable Agriculture, 35(1), 117-125. doi: http://dx.doi.org/10.20961/carakatani.v35i1.34476

\section{INTRODUCTION}

Indonesian traditional markets face challenges due to the presence of modern markets, such as the rise of shopping centers. Traditional markets implement a system of direct bargaining transaction system having the main function to meet the needs of the community at village, subdistrict and district levels (Haryotejo, 2014). Indonesian traditional markets lose sales volume by $17 \%$ because of poor planning, inconvenient access, overcrowded trade activities, lack of air circulation and poor sanitation (Singh et al., 2010; Tanuwidjaja and Wirawan, 2012; Mas et al., 2014; Martin, 2017).

Based on the strategic plan of the Ministry of Agriculture for 2010-2014, traditional markets are related to sustainable agriculture and traditional markets are able to improve farmers' economic condition and welfare by absorbing agricultural products in the countryside. According to economic calculations, conventional farming practice is an appropriate alternative technology to solve food and nutrition shortages, as well as the problem related to food security encountered by the world's population (Rivai and Anugrah, 2011).

The growth of modern markets in Indonesia was marked by the presence of department stores in 1966 (Nelwan et al., 2017). Modern markets can evolve and quickly attract public attention due to the competitive advantages such as cleanliness, a definite price and convenient place (Prabowo et al., 2017). Traditional markets provide inadequate market facilities, compared to department stores,

\footnotetext{
* Received for publication September 9, 2019

Accepted after corrections January 31, 2020
} 
and this potentially reduces the number of visitors (Kuncahyawati, 2016). Market revitali-zation is an action to improve its facilities and services to provide a worthy shopping experience and increase the number of consumers (Hart et al., 2007).

The growth rate of the modern market is faster than that of traditional market, $31.4 \%$ per year and $-8 \%$ per year, respectively (Nielsen, 2010). The rapid growth of modern markets affects traditional markets, shifting consumers' preferences in shopping and lowering production due to reduced number of suppliers (Sheehy, 2004).

The government plays a vital role in setting the regulations and monitoring the management system of traditional markets because in some countries, particularly Indonesia, traditional markets has a significant impact on the country's economy (Ars, 2015). People who shop at traditional markets are always associated with the shopping centers of the lower middle class (Muftiadi and Maulina, 2016).

The growth in the population of Sukoharjo Regency is in line with the increase in community needs, especially food needs. Some of the products that are widely sold in traditional markets are vegetables and fruit. BPS (2016) have noted that the number of consumers of vegetables in Indonesia is higher $(97.29 \%)$ than the number of fruit consumers $(73.59 \%)$. Indonesia's per capita vegetable consumption still needs to be increased to $75 \mathrm{~kg}$ year $^{-1}$, following FAO's recommendations and traders in vegetable industry should consider this (Wijaya, 2012). The vegetables sold in traditional markets are not packed, but the products are commonly fresher because they are taken to the markets in the same day they are harvested.

Consumers today are more efficient in time and rational in making decision to purchase goods (Udiyana et al., 2018). According to the research of Rusnani and Andini (2011), one of the ways to compete with other sellers is marketing strategies, such as the marketing mix strategy to evaluate the performance of each attribute in marketing mix. Hermawan and Solihin (2011) have stated that marketing mix is a tool developed and used as a strategy by a company, specifically in marketing management. Huddleston et al. (2009) have declared that customer satisfaction impacts because prices differ between store formats. Harmon and Foote (2004) also specified that the level of satisfaction decreases when customers have to pay more for goods they think are of the same quality as those sold at lower prices. Consumer satisfaction becomes an important benchmark in measuring marketing performance (Beynon et al., 2010). The purpose of this study was to determine the level of satisfaction of the consumers of fresh vegetables in traditional markets in Sukoharjo.

\section{MATERIALS AND METHOD}

The research locations were selected using purposive sampling technique, by considering the market revitalization program and the extension of the moratorium for the construction of minimarkets until 2030 set in the Regional Regulation Number 6 Year 2016 to maintain the existence of traditional markets. The sampling technique used was using quota sampling technique by taking four consumers as samples per market from 20 traditional markets (Table 1) managed by the Department of Industry and Trade of Sukoharjo Regency with a total of 80 consumers. The study was conducted from January to March 2019.

Buchory and Saladin (2010) have defined satisfaction as happy or unhappy feelings resulted by comparing their expectation and the performance of a product. Zeithaml et al. (2009) have added that satisfaction is a customer's response to the fulfillment of their expectations based on the performance of goods or services they consume. A customer satisfaction index (CSI) needs to be measured because the results obtained can be used as a reference from market management to conduct evaluation and develop strategies to improve customer satisfaction. Besides, the CSI also needs to be identified because customer satisfaction is most effectively measured on a continuous scale.

In this study, data analysis was performed using the CSI. According to Tjiptono (2008), CSI is a step to calculate customer satisfaction level. The steps for measuring CSI are as follows.

1. Determine the Mean Importance Score (MIS-i) or Mean Interest Score and Mean Satisfaction Score (MSS-i) or Average Satisfaction Score

The MIS-i value in this study was obtained from the value of the consumer's interest level divided by the number of respondents, while the MSS-i was obtained from the value of the seller's performance level according to the 
consumer divided by the number of respondents. The formula used was:

$$
M I S_{-i}=\frac{\sum_{i=1}^{n} Y i}{n} \quad M S S_{-i}=\frac{\sum_{i=1}^{n} X i}{n}
$$

Note:

$\mathrm{N}=$ the number of respondents

$\mathrm{Xi}=$ the value of seller's performance level according to consumers

$\mathrm{Yi}=$ the value of consumer interest level

Seller's performance level was "very dissatisfied" when the score was the lowest (1) and "very satisfied" when the score was the highest (5). While consumer importance level was "very unimportant" when the score was the lowest (1) and "very important" when the score was the highest (5).

2. Decide the Weighting Factor (WF-i) or Weighting Interest Score

The WF-i is the value of the average level of importance (MIS-i) of each attribute expressed in percentage of the total MIS-i for each of the attribute tested. The WF-i formula used in this research was:

$$
W F_{-i}=\frac{M I S_{-i}}{\sum M I S}
$$

3. Determine the Weighted Score (WS-i)

The WS-i is a function of MSS-i multiplied by WF-i. MSS-i or the average value of the level of satisfaction in this study was obtained from the average value of the level of customer satisfaction. The formula for measuring WS was:

$$
W S_{-i}=M S S \times W F_{-i}
$$

\section{Determine the Total Weight (WT)}

The WT is a function of the $1^{\text {st }}$ total WS to the $\mathrm{n}^{\text {th }}$ attribute.

$$
W T=W S_{1}+W S_{2}+W S_{3}+\ldots \ldots W S_{n}
$$

\section{Calculate the Satisfaction Index}

Satisfaction Index in this study was WT divided by the maximum scale used then multiplied by $100 \%$.

$$
C S I=\frac{C S I}{H S} \times 100 \%
$$

Note:

$\mathrm{WT}=$ total score

HS = maximum scale used (the higest Likert scale $=5)$

Table 1. Traditional markets in Sukoharjo

\begin{tabular}{cll}
\hline No. & \multicolumn{1}{c}{ Traditional Market } & \multicolumn{1}{c}{ Address } \\
\hline 1. & Tawangsari & Kateguhan 001/002, Tawangsari, Tawangsari \\
2. & Ngalian & Lorog 001/001, Tawangsari, Tawangsari \\
3. & Watukelir & Watukelir, Jatingarang, Weru \\
4. & Tawangkuno & Jl. Pattimura, Tawang, Weru \\
5. & Bulu & Soronanggan 003/005, Bulu \\
6. & Lengking & Lengking 002/004, Lengking \\
7. & Ir. Soekarno & Jl. Jendral Sudirman No. 35 Sukoharjo \\
8. & Carikan & Jl. Raya Carikan, Sukoharjo \\
9. & Grogol & Jl. Raya Grogol, Sukoharjo \\
10. & Telukan & Jl. Raya Telukan Sukoharjo \\
11. & Cuplik & Tegalsari 001/001, Bulakan, Sukoharjo \\
12. & Kedunggudel & Kedunggudel 001/003, Kenep, Sukoharjo \\
13. & Sraten & Sraten, Gatak, Sukoharjo \\
14. & Mayang & Saripan, Mayang, Gatak \\
15. & Kartasura & Jl. Ahmad Yani, Kartasura \\
16. & Baki & Ngablak 001/004, Kudu, Baki \\
17. & Bekonang & Jl. Pemuda N0.57, Bekonang \\
18. & Mulur & Mulur 001/001, Mulur, Bendosari \\
19. & Glondongan & Glondongan, Mranggen, Polokarto \\
20. & Sedayu & Kepuh, Bulu, Polokarto \\
\hline
\end{tabular}


The level of customer satisfaction can be seen from the criteria of the level of customer satisfaction. The highest satisfaction will be achieved if the CSI in the customer satisfaction criteria shows a range of $100 \%$. CSI level criteria in the marketing mix for traditional markets are $0.000, \mathrm{n} \leq 20.99$ in the very dissatisfied category, $21.00 \leq \mathrm{n} \leq 40.00$ in the dissatisfied category, $41.00 \leq \mathrm{n} \leq 60.99$ in the category moderate, 61.00 $\leq \mathrm{n} \leq 80.99$ in the satisfied category and $81.00 \leq \mathrm{n}$ $\leq 100$ in the very satisfied category (Maryono et al., 2016).

\section{RESULTS AND DISCUSSION}

Sukoharjo Regency is divided into 12 subdistricts, namely Baki, Bendosari, Bulu, Gatak, Grogol, Kartasura, Mojolaban, Nguter, Polokarto, Sukoharjo, Tawangsari and Weru and each subdistrict has a center of economic activity taking form of traditional market under the management of the Department of Industry and Trade of Sukoharjo Regency. This will immediately move the economy and the progress of the community. Most traditional markets in there operate from 05:00 a.m. to 4:00 p.m. The products marketed in traditional markets in this regency are diverse, including foods, vegetables, fruits, meat, fish and chicken, processed foods, electronics and household utensils. To support the activities of buying and selling, traditional markets under the management of the Department of Industry and Trade are equipped with permanent and nonpermanent buildings and other supporting facilities such as places of worship, public toilets and security posts.

Based on the results of the study, the majority of consumers purchasing goods at traditional markets were female with a percentage of $78.75 \%$, while the male consumers reached $21.25 \%$. This shows that women's interest in shopping at traditional markets was greater than that of men for the reason that shopping at traditional markets tended to be closer to women's activities for daily shopping. Besides, the female consumers had more thorough and detailed characteristics in shopping and were more adept at negotiating in transactions. The results also indicate that the majority of traditional market consumers were sellers $(58.89 \%)$, followed by housewives (28.98\%) and farmers, civil servants, etc. $(12.13 \%)$.
An individual's consumption level is determined by their income. When the income is higher, the consumption will tend to rise (Rahardja and Manurung, 2004). This will have an impact on the ability or the purchasing power of the people and their responses to the facilities or shopping centers. The results of the study reveal that, the consumers purchasing vegetables in traditional markets were varied. $78.75 \%$ of the consumers had an income of between IDR $1,000,000$ and IDR 3,000,000, while $2.5 \%$ of them had more than IDR 5,000,000. This signifies that traditional market was the choice for most of the people in research location for shopping, especially the consumers with lower middle income, ranging from IDR $1,000,000$ to IDR $3,000,000$.

The satisfaction level of consumers purchasing vegetables in traditional markets with mix products was analyzed using the CSI. The results of the analysis are presented in Table 2 . In the analysis of consumer level, satisfaction can be seen as the extent to which the level of performance or implementation of the observed attributes can meet the needs or expectations of consumers. The highest WS value on the product attribute was the diversity of products with a value of 0.190. According to consumers, the need for a variety of vegetables is always available in the traditional markets, which makes it easier for consumers to shop because consumers do not need to shop in several places to meet the needs of vegetables. Following Sari and Setyowati (2017); Hadita (2018), product quality in the form of product diversity significantly influences customer satisfaction in traditional markets in (Saputra, 2015) and people choose to shop for vegetables in traditional markets because the vegetables are believed to be fresher and lower in prices (Timoer and Trenggana, 2019).

The highest WS value on the price attribute was the price of the product following the expectations of consumers, which was 0.162 . The consumers of traditional markets specified that the price of vegetables in accordance with what was expected would provide satisfaction to consumers because consumer satisfaction would arise based on the match between expectations and the reality. According Herrmann et al. (2007); Salvador et al. (2007) and Wang (2014), customer satisfaction can be achieved when the price they pay for a product is quite in accordance with their 
perceptions. Customer satisfaction is basically the difference between the expected and observed values of goods and/or services purchased and also directly proportional to the perception of price compared to quality. Levens (2010) has suggested that price is the cost of exchange of an item/service in a market. In other words, consumers feel that the cost of exchanging goods (vegetables) is based on their expectations. Traditional market are the manifestation of cultural value of applying more open buying and selling activities such as hospitality in transactions to reach an agreement on price and unfixed price so that bargaining can be possibly done (Prastyawan et al., 2015; Sahban and Periwa, 2018). Price is the only marketing mix element that generates revenue; therefore, price competition is a vital issue encountered by sellers to seize market share.

Table 2. Analysis of CSI value calculation of all marketing mix attributes of the consumers of vegetables

\begin{tabular}{|c|c|c|c|c|}
\hline $\begin{array}{l}\text { Atributtes } \\
(1)\end{array}$ & $\begin{array}{c}\text { MIS } \\
(2)\end{array}$ & $\begin{array}{c}\text { WF } \\
(3)=(2) / \text { total }\end{array}$ & $\begin{array}{c}\text { MSS } \\
(4)\end{array}$ & $\begin{array}{c}\text { WS } \\
(5)=(3 \times 4)\end{array}$ \\
\hline \multicolumn{5}{|l|}{ Product } \\
\hline Product diversity & 4.289 & 0.049 & 3.920 & 0.190 \\
\hline $\begin{array}{l}\text { Consumers get information on the product } \\
\text { specification }\end{array}$ & 3.789 & 0.043 & 3.511 & 0.150 \\
\hline Product freshness & 4.122 & 0.047 & 3.833 & 0.179 \\
\hline \multicolumn{5}{|l|}{ Price } \\
\hline Product prices are in line with expectations & 3.978 & 0.045 & 3.611 & 0.162 \\
\hline Product prices can be negotiable & 3.300 & 0.037 & 3.811 & 0.142 \\
\hline Price developments are known by sellers & 3.711 & 0.042 & 3.178 & 0.133 \\
\hline Cheaper product prices & 3.044 & 0.034 & 3.478 & 0.120 \\
\hline \multicolumn{5}{|l|}{ Place } \\
\hline Good product availability & 4.100 & 0.046 & 3.711 & 0.172 \\
\hline Kiosk has identity/plank & 2.756 & 0.031 & 1.756 & 0.055 \\
\hline \multicolumn{5}{|l|}{ Promotion } \\
\hline $\begin{array}{l}\text { Get additional free products to purchase a certain } \\
\text { amount }\end{array}$ & 3.811 & 0.043 & 3.222 & 0.139 \\
\hline Discounted product prices from sellers & 4.078 & 0.046 & 3.556 & 0.164 \\
\hline Word of mouth promotion & 3.144 & 0.036 & 3.244 & 0.115 \\
\hline $\begin{array}{l}\text { Promotional information from sellers through the } \\
\text { media (cellphones/leaflets) }\end{array}$ & 1.633 & 0.018 & 1.267 & 0.023 \\
\hline \multicolumn{5}{|l|}{ People } \\
\hline Sellers are friendly to buyers & 4.322 & 0.049 & 3.622 & 0.177 \\
\hline Sellers apply honesty & 4.244 & 0.048 & 3.633 & 0.174 \\
\hline Sellers serve buyers swiftly & 4.011 & 0.045 & 3.611 & 0.164 \\
\hline The sellers manages their own business & 3.756 & 0.042 & 3.556 & 0.151 \\
\hline \multicolumn{5}{|l|}{ Process } \\
\hline Flexible payment process & 3.800 & 0.043 & 2.567 & 0.110 \\
\hline Ordering products for delivery & 3.667 & 0.041 & 3.389 & 0.141 \\
\hline The packaging process is done well & 1.911 & 0.022 & 3.600 & 0.078 \\
\hline \multicolumn{5}{|l|}{ Physical Evidence } \\
\hline $\begin{array}{l}\text { Cleanliness of shopping places is always } \\
\text { maintained }\end{array}$ & 4.378 & 0.050 & 3.456 & 0.171 \\
\hline Consumers are free in shopping & 4.244 & 0.048 & 3.756 & 0.180 \\
\hline The market is strategically located & 4.356 & 0.049 & 3.922 & 0.193 \\
\hline $\begin{array}{l}\text { Products are arranged neatly according to the type } \\
\text { of product }\end{array}$ & 3.978 & 0.045 & 3.544 & 0.159 \\
\hline \multirow[t]{2}{*}{ Total } & 88.42 & & & 3.445 \\
\hline & & & & $69 \%$ \\
\hline
\end{tabular}


The highest WS on the place attribute was the availability of good products, which was valued 0.172 . Product availability is a major consideration for consumers in the traditional markets because products are always available; thus, consumers will be satisfied if the product sought is always available in the markets. On the contrary, consumers will be disappointed if the products are out of stocks. Haris et al. (2018) have detailed that the availability of products influences consumer satisfaction.

The highest WS value on the promotion attribute was the discounted product price provided by the sellers, which was 0.164 . The consumer gave details that the cutprice of the product gave more benefits, compared to the other attributes. The additional attributes of free products in this study occupy the second position below the discounted price from the seller because the free products are not suitable with the consumers' desires. Word of mouth promotion is commonly carried out by sellers in traditional market because after they directly meet consumers, the consumers will inform others about the services provided and the goods marketed. Promotion through information media is used by the sellers as a way of communicating the goodness of the marketed product to the buyer so that the buyer is interested in purchasing the offered product. Promotion is carried out by traditional market traders in Sukoharjo to encourage consumers to buy the products offered. In other words, the promotion aims to increase sales turnover by influencing consumers. Pangastuti (2017) has stated that price discount is one of the factors that determine consumer satisfaction in shopping.

The highest WS in the people attribute was the friendly seller. In traditional markets that involve bargaining process, consumers have direct interactions with sellers. As a routine activities, the interactions give a chance for both consumers and sellers to establish better relationships (Utomo, 2011). This is supported by the research of $\mathrm{Wu}$ and $\mathrm{Li}$ (2017) which found that from a marketing perspective, customers with good experience will have a higher intention to buy the same product or re-visit the store. The same thing was shown by Saputra (2015) that service is a key factor as a basis for customers to choose the products offered. The available facilities, as well as the responsiveness and readiness of sellers in providing services to consumers become a key factor in the impression that will be felt by customers while in the market.

The highest WS on the process attribute was an order to be delivered. The consumers explained that certain traders are normally willing to carry out the process of sending a certain number of products. Orders are made when consumers are going to hold a celebration or other activities. This gives satisfaction to consumers because it facilitates the shopping process, especially in terms of time and energy, according to Johannes et al. (2009) who have stated that simplicity in the transaction process provides a positive relationship to customer satisfaction.

The highest WS in the physical evidence attribute was the market located in a strategic location, which was valued 0.193 . The access to the traditional markets are generally easy, because the areas are accessible to public and private vehicles to satisfy consumers. Saputra (2015) has noted that the perception of a good location will affect customer satisfaction. Location is a factor that plays a role in consumer satisfaction in spending money to buy goods or services.

From the results of data analysis using the CSI method, a value of $69 \%$ was obtained. This value falls into "satisfied" category because the CSI value ranges from $60 \%<$ CSI $<80 \%$. This shows that consumers are mostly satisfied with the performance of vegetable sellers in the traditional markets in research area. Most of the attributes attached to traditional markets have a good image in the eyes of consumers so as to get a good satisfaction index. Consumers are satisfied with services provided in traditional markets that still prioritize the family system so that it gives comfort to consumers in their transaction with sellers. However, sellers should maintain and improve their good on the attributes that are the main consideration of consumers in shopping. This is intended to improve the performance of traditional markets so that consumers continue to survive in these markets, and with improved management performance, the consumer satisfaction can always be improved in shopping.

\section{CONCLUSIONS}

Based on the value of CSI, consumers are satisfied with the performance of the seller of fresh vegetable in the traditional markets in Sukoharjo Regency. The attribute of the 
marketing mix that provides the highest level of satisfaction is the markets that are strategically located. Marketing mix attribute causing the lowest level of satisfaction is promotional information from sellers through the media.

\section{REFERENCES}

Ars. (2015). Peran Pasar Tradisional sebagai Pondasi Dasar Ekonomi Kerakyatan. Retrieved from https://dpd.go.id/artikel-957peran-pasar-tradisional-sebagai-pondasi-dasar -ekonomi-kerakyatan

Beynon, M. J., Moutinho, L., \& Veloutsou, C. (2010). Gender Differences in Supermarket Choice: An Expositional Analysis in the Presence of Ignorance using CaRBS. European Journal of Marketing, 44(1-2), 267290. https://doi.org/10.1108/03090561011008 709

Badan Pusat Statistik, [BPS]. (2016). Konsumsi Buah dan Sayur Susenas Maret 2016. Jakarta. https://www.bps.go.id/publication/2016/12/29 /d24af3004eb8eee4fc402115/pengeluaran-unt uk-konsumsi-penduduk-indonesia-maret-2016 .html

Buchory, H. A., \& Saladin, D. (2010). Manajemen Pemasaran. Bandung: Linda Karya.

Hadita. (2018). Dampak Keragaman Produk terhadap Kepuasan Pelanggan Ramayana Departemen Store. Jurnal Riset Manajemen dan Bisnis (JRMB), 3(3), 365-374. https://doi. org/10.36226/jrmb.v3i3.154

Haris, S. T. P., Maulidya, N. P., Desari, L. C., \& Dewi, A. C. (2018). Analisis Pengaruh Kenyamanan, Ketersediaan, dan Keamanan Pelayanan Kampus terhadap Kepuasan Mahasiswa UPN "Veteran" Jakarta (UPNVJ). Seminar dan Konferensi Nasional IDEC 2018 Surakarta. Retrieved from https://docplayer. info/81124155-Analisis-pengaruh-kenyamana n-ketersediaan-dan-keamanan-pelayanan-kam pus-terhadap-kepuasan-mahasiswa-upn-vetera n-jakarta-upnvj.html

Harmon, S. K., \& Foote, D. A. (2004). The Influence of Price Difference and Equity Sensitivity on Customer Satisfaction in a Dynamic Pricing Environment. NA - Advances in Consumer Research, 31, 593-598. Retrieved from https://www.acrwebsite.org/volumes/89 76/volumes/v31/na-31

Hart, C., Farrell, A. M., Stachow, G., Reed, G., \& Cadogan, J. W. (2007). Enjoyment of the Shopping Experience: Impact on Customers' Repatronage Intentions and Gender Influence. Service Industries Journal, 27(5), 583-604. https://doi.org/10.1080/02642060701411757

Haryotejo, B. (2014). Dampak Ekspansi Hypermarket terhadap Pasar Tradisional di Daerah. Jurnal Bina Praja, 6(3), 241-248. https://doi.org/10.21787/jbp.06.2014.241-248

Hermawan, M., \& Solihin, S. (2011). Usulan Strategi Pemasaran Produk Garam (Studi Kasus: Produk Garam Karya Tani). Jurnal Integra, 2(1), 77-94. Retrieved from http://id. portalgaruda.org/?ref=browse \&mod=viewarti cle $\&$ article $=279427$

Herrmann, A., Xia, L., Kent, M. B., \& Huber, F. (2007). The Influence of Price Fairness on Customer Satisfaction: An Empirical Test in the Context of Automobile Purchases. Journal of Product and Brand Management, 16(1), 4958. https://doi.org/10.1108/106104207107311 51

Huddleston, P., Whipple, J., Mattick, R. N., \& Lee, S. J. (2009). Customer Satisfaction in Food Retailing: Comparing Specialty and Conventional Grocery Stores. International Journal of Retail and Distribution Management, 37(1), 63-80. https://doi.org/10. 1108/09590550910927162

Johannes, Raf, M., \& Lukman, M. (2009). Analisis Kepuasan Nasabah Prioritas berdasarkan Bauran Pemasaran (Kasus pada PT. Bank Central Asia, Tbk Kantor Cabang Utama Jambi). Jurnal Manajemen Pemasaran Modern, 1(1), 35-45. Retrieved from https:// online-journal.unja.ac.id/pemasaran/article/vi ew/501

Kuncahyawati, H. (2016). Pemberdayaan Pasar Tradisional dan Pedagang Pasar Menurut Peraturan Daerah Kabupaten Purworejo Nomor 6 Tahun 2014. 1-17. Retrieved from http://repository.umy.ac.id/bitstream/handle/1 23456789/7548/JURNAL.pdf

Levens, M. (2010). Marketing: Defined, Explained, Applied, International Edition. New Jersey: Pearson Education Limited. 
Martin, I. (2017). Penerapan Kebijakan Zonasi Dalam Penataan Pasar Tradisional dan Pasar Modern Kota Bandung (Suatu Tinjauan Yuridis dari Perspektif Otonomi Daerah). Jurnal Wawasan Yuridika, 1(2), 107-138. https://doi.org/10.25072/jwy.v1i2.131

Maryono., Effendi, H., \& Krisanti. M. (2016). Analisis Kepuasan Wisatawan untuk Manajemen Pantai di Wisata Pantai Tanjung Bira. Jurnal Pariwisata, 3(2), 94-104. Retrieved from https://ejournal.bsi.ac.id/ejur nal/index.php/jp/article/view/1352

Mas, N., Thoyib, A., Surachman, S., \& Solimun, S. (2014). Trader Sturdiness at Traditional Market in Facing Modern Market Progress. International Journal of Business and Management Invention, 3(5), 49-58. Retrieved from https://www.ijbmi.org/papers/Vol(3)5/V ersion-3/F0353049058.pdf

Muftiadi, R. A., \& Maulina, E. (2016). The Business Dynamic of Traditional Market Place: Demand Preferencae Approach. AdBispreneur : Jurnal Pemikiran dan Penelitian Administrasi Bisnis dan Kewirausahaan, 1(2), 113-126. https://doi. org/10.24198/adbispreneur.v1i2.10234

Nelwan, J. W., Lapian, S. L. H. ., \& Rumokoy, F. S. (2017). The Existence Traditional Market Toward Modern Market in Tomohon City. Emba: Jurnal Riset Ekonomi, Manajemen, Bisnis Dan Akuntansi, 5(3), 3348-3355. Retrieved from https://ejournal.unsrat.ac.id/ index.php/emba/article/view/17511

Nielsen. (2010). Retail and Shopper Trends Asia Pacific 2010 - The latest in retailing and shopper trends for the FMCG industry. Retrieved from https://www.nielsen.com/wpcontent/uploads/sites/3/2019/04/Retail-and-Sh opper-Trends-2010.pdf

Pangastuti, R. L. (2017). The Influence of Experiential Marketing And Service Quality For being Reasonability of Customers Loyality Forming (Case Study of Beauty Saloon of London Beauty Center "LBC"). Ekonika: Jurnal Ekonomi Universitas Kadiri, 2(2), 198213. https://doi.org/10.30737/ekonika.v2i2.43

Prabowo, E., Madi, Safri, \& Lustrilanang, P. (2017). Existence and Revitalization of Traditional Markets against Modern Markets
Development. Journal of Basic and Applied Scientific Research, 7(1), 1-16. Retrieved from https://www.textroad.com/pdf/JBASR/J.\%20 Basic.\%20Appl.\%20Sci.\%20Res.,\%207(1)116,\%202017.pdf

Prastyawan, A., Suryono, A., Saleh Soeaidy, M., \& Muluk, K. (2015). Revitalization of Traditional Markets into a Modern Market in the Perspective of Local Governance Theory (Studies on Revitalization Wonokromo Market in Surabaya). IOSR Journal of Humanities And Social Science Ver. IV, 20(9). 1-6. https://doi.org/10.9790/0837-20940106.

Rahardja, P dan Manurung, M. (2004). Teori Ekonomi Makro: Suatu Pengantar (2nd ed.). Jakarta: Fakultas Ekonomi Universitas Indonesia.

Rivai, R. S., \& Anugrah, I. S. (2011). Konsep dan Implementasi Pembangunan Pertanian Berkelanjutan di Indonesia. Forum Penelitian Agro Ekonomi, 29(1), 13-25. https://doi.org/ 10.21082/fae.v29n1.2011.13-25

Rusnani., \& Andini, I. Y. (2011). Strategi Pemasaran Batik Madura dalam Menghadapi Pemasaran Global. Jurnal Performance "Bisnis dan Akuntansi", 4(2), 14-25. Retrieved from http://garuda.ristekbrin.go.id/documents/ detail/1117425

Sahban, H., \& Periwa, I. (2018). Empowerment of Traders and Traditional Market Potential Development in Indonesia. International Journal of Innovative Science and Research Technology, 3(1), 428-436. Retrieved from https://ijisrt.com/empowerment-of-traders-an d-traditional-market-potential-developmentin-indonesia

Salvador, C., Rebolloso, E., Fernández-Ramírez, B., \& Cantón, M. del P. (2007). Service Price Components and Their Relationship with Customer Satisfaction. Journal of Revenue and Pricing Management, 6(1), 40-50. https:// doi.org/10.1057/palgrave.rpm.5160057

Saputra, A. (2015). Pengaruh Lokasi, Kualitas Produk dan Kualitas Pelayanan terhadap Kepuasan Konsumen Pasar Tradisional (Studi Kasus Pasar Tradisional di Kecamatan Medan Johor). Jurnal Manajemen Bisnis STIE IBBI, 23(1), 10-19. Retrieved from https://osf.io/ 9fyd $7 /$ download/?format=pdf 
Sari, N., \& Setyowati, S. (2017). Pengaruh Keragaman Produk dan Kualitas Pelayanan terhadap Kepuasan Konsumen di PB Swalayan Metro. Jurnal Manajemen Magister Darma jaya, 3(2), 186-199. Retrieved from https:// jurnal.darmajaya.ac.id/index.php/jmmd/article /view/992/0

Sheehy, B. (2004). Corporations And Social Costs: The Wal-Mart Case Study. Journal Of Law And Commerce, 24(1), 1-53. Retrieved from https://papers.ssrn.com/sol3/papers.cfm? abstract_id $=2156751$

Singh, V. P., Hansen, K. T., \& Blattberg, R. C. (2010). Market Entry and Consumer Behavior:An Investigation of a Wal-Mart Supercenter. Perspectives on Promotion and Database Marketing, 310-329. https://doi.org/ 10.1142/9789814287067_0019

Tanuwidjaja, G., \& Wirawan, R. (2012). Creative - Sustainable Traditional Market Design in Malang. The 2nd International Conference Planning in the Era of Uncertainty: Sustainable Development, 11. Retrieved from http://repository.petra.ac.id/17011/

Timoer, F. C., \& Trenggana, A. F. M. (2019). Analisis Perbandingan Karakteristik Pasar Tradisional dan Pasar Modern Ditinjau dari Strategi Bauran Pemasaran di Kota Bandung (Studi Kasus pada Pasar Palasari dan Griya Buah Batu). Jurnal Ilmiah MEA (Manajemen, Ekonomi, \& Akuntansi), 3(3), 219-226. Retrieved from http://journal.stiemb.ac.id/ind ex.php/mea/article/view/157

Tjiptono, F. (2008). Strategi Pemasaran.
Yogyakarta : Andi.

Utomo, T. J. (2011). Persaingan Bisnis Ritel: Tradisional vs Modern (The Competition of Retail Business: Traditional vs Modern). Fokus Ekonomi, 6(1), 122-133. Retrieved from https://stiepena.ac.id/wp-content/uploads/201 2/11/pena-fokus-vol-6-no-1-122-133.pdf

Wang, D. (2014). The Study And Use Of AHP In Logistics and Customer Satisfaction. BioTechnology: An Indian Journal, 10(9), 3515-3520. Retrieved from https://www.tsi journals.com/abstract/the-study-and-use-of-ah p-in-logistics-and-customer-satisfaction-9548. html

Wijaya, K. A. (2012). Pengantar Agronomi Sayuran. Jakarta : Prestasi Pustakaraya.

Udiyana, I. B. G., Astini, N. Y. S., Parta, I. N., \& Dewantari, N. W. M. (2018). Pendekatan Marketing Mix Implikasinya terhadap Keputusan Pembelian Wisatawan di Pasar Seni Tradisional. Prosiding Seminar Nasional Hasil Penelitian - Denpasar, 251-264. Retrieved from https://ojs.stimihandayani.ac .id/index.php/prosiding/article/view/239

Wu, H. C., \& Li, T. (2017). A Study of Experiential Quality, Perceived Value, Heritage Image, Experiential Satisfaction, and Behavioral Intentions for Heritage Tourists. Journal of Hospitality \& Tourism Research, 41(8), 904-944. https://doi.org/10.1177/1096 348014525638

Zeithaml, V. A., Bitner, M. J., \& Gremier, D. (2009). Services Marketing (5th ed.). New York City: McGraw-Hill. 